\title{
KONSERWACJA I REKONSTRUKCJA RĘKAWICY SKÓRZANEJ Z WYSPY SPICHRZÓW W GDAŃSKU
}

SŁowA KLUCzowe: Gdańsk, rękawica skórzana, konserwacja, freeze-drying KEYwORDs: Gdańsk, leather glove, conservation, freeze-drying

\section{KRÓTKA HISTORIA RĘKAWICZEK}

Trudno jednoznacznie stwierdzić kiedy człowiek zaczął produkować i używać rękawic. Już płaskorzeźba egipska z XIV w. p.n.e. wskazuje, że osoby wysoko sytuowane społecznie mogły nosić kolorowe okrycia rąk, spełniające prawdopodobnie funkcję darów królewskich. Wzmianki o wykorzystywaniu ochrony palców i rąk na polu bitwy znajdują się również w opisach biblijnych, a Spartanie przywdziewali rękawice ułatwiające chwyt natartego oliwą ciała w trakcie rozgrywania zapasów (Eberle 1970: 260). Pierwsza wzmianka o tych elementach odzieży pochodzi z I wieku przed Chrystusem, a pojawia się w dziele traktującym o rolnictwie autorstwa Marka Terencjusza Warrona. Pisarz wspomina w nim, że robotnicy zrywający oliwki zakładali je w celu ochrony rąk. W okresie średniowiecza rękawiczki zyskały z kolei złożoną symbolikę. Stały się wyrazem godności i władzy, a także honoru czy uczucia. Występowały często w trakcie pojedynków, nadań ziemskich czy znaczących transakcji handlowych (Eberle 1970: 260-261; Turnau 1983: 25). Na terenie ziem polskich pierwsze źródła historyczne wspominają o rękawiczkach dopiero w XIV i XV w. Wtedy też dochodzi do rozwoju rzemiosła i specjalizacji tej gałęzi. Najważniejszymi ich wytwórcami były organizacje cechowe miechowników, a później rękawicznicy. Produkcją, w zależności od regionu, zajmowali się także kaletnicy czy kuśnierze (Eberle 1970: 261-262; Turnau 1975a: 137-139, 150-151, 152). O popularności tego elementu odzieży może świadczyć fakt, że produkcja krajowa była niewystarczająca dla potrzeb lokalnych, a w nowożytnym Gdańsku mieszkańcy nabywali niekiedy po kilkadziesiąt par rękawic różnej jakości miesięcznie. Otwierało to rynek dla kupców zagranicznych, przywożących je do miasta np. ze Szkocji (Eberle 1970: 262). 
Okrycia rąk wykonywano w rozmaitych wariantach, różniących się między sobą nie tylko krojem, ale sposobem wykańczania, zdobieniem czy surowcem wykorzystanym do ich produkcji. Używano skór pozyskiwanych zarówno ze zwierząt dzikich, jak i hodowlanych (Eberle 1970: 262), ceniąc sobie surowiec elastyczny i wytrzymały zarazem (Turnau 1975a: 152-153). Wyprawą delikatnych skórek zajmowali się białoskórnicy, stosując do garbowania papki składające się z mąki lub otrębów pszennych, żółtek jaj, ałunu, soli kuchennej i tłuszczu (Eberle 1970: 262; Turnau 1975b: 96-97).

Rękawice, podobnie jak inne elementy odzieży, podlegały modyfikacjom i przekształceniom zależnym od aktualnie panujących trendów. Nie bez znaczenia było również ich przeznaczenie. Wyróżnić więc można ich dwie główne kategorie: ochronne, a także wytworne (Eberle 1970: 263), których funkcja pozwalała na znacznie lżejszą konstrukcję i użycie delikatniejszych surowców do ich produkcji.

Średniowieczne, wykonywane ze skóry i zaopatrzone w wyodrębniony kciuk mogły pełnić więc funkcję roboczą, jako ochrona ręki przy wykonywaniu fizycznej pracy przez m.in. murarzy, kamieniarzy, cieślów, a także przy pracach bardziej precyzyjnych, wymagających jednak używania ostrych narzędzi jak np. igły, szydła, przebijaki szewskie. Pewne formy okrycia ręki wykorzystywali również myśliwi polujący z ptakami drapieżnymi - sokolnicy czy jastrzębnicy (Eberle 1970: 263). Ostre szpony ptaków wymagały zapewne użycia grubych, wytrzymałych skór.

\section{SKóRZANa RĘKAWICA Z GdAŃSKA}

W trakcie prac archeologicznych prowadzonych w obrębie reliktów spichrza „Babel” przy ul. Żytniej 2 w Gdańsku', w warstwach oznaczonych jako 670 oraz 671 natrafiono na przedmiot skórzany (ryc. 1), który po wstępnym oczyszczeniu z pozostałości wilgotnej gleby oraz mierzwy okazał się fragmentem skórzanej rękawicy, w literaturze określanej jako jednopalczasta (nr inw. 789/2016). Jej krój umożliwia stwierdzenie, że zakładana była na prawą rękę (ryc. 3).

Ten rodzaj znalezisk znajduje się sporadycznie w zbiorach zabytków skórzanych pochodzących z polskich i zagranicznych stanowisk archeologicznych. Podobną krojem rękawicę odnaleziono na Starym Mieście w Warszawie, a jej datowanie określono na XIV w. (Eberle 1970: 264). Z badań prowadzonych w Kaliszu przy ul. Targowej pochodzi model z poszerzonym mankietem. Również jej chronologię określono na XIV w. Starsze, XIII-wieczne skórzane okrycie ręki z wyodrębnionym kciukiem odnaleziono we Wrocławiu, przy

${ }^{1}$ Dziękuję Pani mgr Renacie Wiloch-Kozłowskiej za udostępnienie materiałów z badań na Wyspie Spichrzów - badania 2016. 
ul. Św. Katarzyny. Z lewobrzeżnego Wrocławia pochodzą najstarsze, datowane na XI w. Na podstawie wyglądu określić je można jako skromne, pełniące funkcje odzieżowe lub ochronne (Samsonowicz 1982: 100, ryc. 25; Turnau 1983: 25). Z Pskowa pochodzi kilka rękawic, w tym jednopalczaste, wykonane z jednego fragmentu skóry, z doszywanym wykrojem kciuka. Drugi wariant odnalezionych w Pskowie zabytków wykonywano z dwóch połówek, do których doszywano wykrój kciuka. Jedne z najstarszych pochodzą z Nowogrodu Wielkiego. Również tam zaobserwowano dwa warianty wykrojów - jednoczęściowe $\mathrm{z}$ doszywanym kciukiem oraz te wykrawane $\mathrm{z}$ dwóch połówek z doszytym kciukiem. Rękawice z Nowogrodu datowano szeroko na okres od XI-XIV w., a analogiczne znaleziska zaobserwowano także w materiałach pochodzących z Moskwy (Eberle 1970: 263-264; Samsonowicz 1982: 99) i w Sandomierzu (Turnau 1983: 26).

Bardzo podobne rękawice do gdańskiej odnaleziono w Kołobrzegu przy ul. Ratuszowej oraz przy ul. E. Gierczak (Wywrot 1996: 279; Rębkowski i in. 1998: 124, 127; Wywrot-Wyszkowska 1998: 245, ryc. VIII: 4; 2008: 197, tabl. XXXII). Jedną z nich, zaopatrzoną w mankiet, wykonano ze skóry zwierzęcia $\mathrm{z}$ rodziny jeleniowatych, $\mathrm{z}$ kolei $\mathrm{w}$ przypadku drugiej nie przeprowadzono analizy gatunkowej (Wywrot-Wyszkowska 1998: 245-246; 2008: 68).

Prawdopodobnie największy zbiór zbliżonych stylistycznie rękawic skórzanych pochodzi z Gdańska. W trakcie badań archeologicznych prowadzonych przez Muzeum Archeologiczne w Gdańsku zarejestrowano fragmenty ok. 80 egzemplarzy, z czego aż $97 \%$ zabytków uznano za jednopalczaste o kroju jedno lub dwuczęściowym z doszytym wykrojem kciuka (Ceynowa 2009: 229-230). W zbiorze znalazły się warianty zarówno na lewą jak i prawą rękę, noszone przez dorosłych i dzieci, być może terminatorów rzemieślniczych lub młodocianych pracowników fizycznych z pobliskich stoczni i portów (Ceynowa 2009: 232).

\section{STAN ZACHOWANIA I PRZYCZYNY ZNISZCZEŃ}

Gdańska rękawica przetrwała w dobrym stanie, choć w trakcie depozycji lub eksploracji została zdekompletowana. Zachował się jednoczęściowy korpus zabytku, zwany w literaturze przedmiotu gryfem, obejmujący mankiet, część śródręcza oraz palców. W partii opuszków dostrzegalne są znaczne ubytki struktury zabytku, brakuje również całego wykroju kciuka (ryc. 2). Na powierzchni lica skóry zaobserwowano liczne spękania i płytkie przetarcia, nie przerywające jednak mizdry. Krawędzie skóry w okolicy ubytków poznaczone są głębokimi spękaniami lub rozdarciami powstałymi na skutek uszkodzeń mechanicznych (Nowak 2017: 3-4). Warto nadmienić, że otwór pod wykrój kciuka, tzw. anewir (Ceynowa 2009: 230) wykonano starannie, zaopatrując go w języczek, który 
następnie wszywano w szew kciuka, co w znacznej mierze wpływało na wytrzymałość gotowego produktu i przedłużało jego żywotność (Ceynowa 2009: 230, 232).

Zabytek swoją kondycję zawdzięcza wilgoci oraz stałym warunkom panującym w miejscu jego depozycji. Zastopowanie procesów rozkładu nastąpiło dzięki ograniczeniu ekspozycji zabytku na światło słoneczne oraz dostępu tlenu (Ceynowa 2009: 229; Grupa 2011: 31-32; 2014a: 302). Na skutek wypłukiwania substancji dostarczonych skórze w trakcie procesu garbowania (Rosa i in. 1995: 207), dochodzi do utraty pierwotnych właściwości oraz odporności skóry na czynniki mechaniczne i chemiczne, co spowodowane jest w dużej mierze rozkładem kolagenu (Turnau 1975b: 95-96; Grupa 2011: 31). W wyniku zalegania w glebie skóra narażona jest ponadto na działanie związków taninowych, żelazistych oraz kwasów humusowych, które wnikają w strukturę zabytku zmieniając jego barwę, najczęściej na ciemnobrunatną, brązową lub czarną (ryc. 1) (Rosa i in. 1995: 208; Grupa 2011: 31). Zabytki skórzane zdeponowane w ziemi narażone są również na działanie rozmaitych mikroorganizmów (Rosa $i$ in. 1995: 206).

Jednym $z$ bardziej newralgicznych momentów dla zabytku jest chwila jego odkrycia przez archeologa. Skóra odzyskuje kontakt ze światłem i zmiennymi warunkami atmosferycznymi (Grupa 2014a: 302; 2014b: 126). Wyeksplorowana ze stałego środowiska, zaczyna podlegać zmianom temperatury i wilgotności, co naraża ją na wysychanie, a w efekcie na deformacje spowodowane sklejaniem się komórek (Grupa 2011: 31-32; 2014b: 135). Mikroorganizmy, które dotychczas pozostawały uśpione, namnażają się i żerują na powierzchni zabyt$\mathrm{ku}$, co znacznie przyspiesza proces jego degradacji i rozkładu.

\section{CEL I ZALOŻENIA KONSERWACJI ORAZ REKONSTRUKCJI ZABYTKU}

Celem przeprowadzanych prac konserwatorskich było zabezpieczenie zabytku przed dalszą degradacją, a także scharakteryzowanie technologii jego wykonania. Stan zachowania rękawicy umożliwił odtworzenie jej kształtu i brakujących elementów. Rekonstrukcja miała na celu przygotowanie rękawicy do ekspozycji w kontrolowanych warunkach muzealnych, a także ułatwienie odbioru jej formy i treści zwiedzającym Muzeum Historii Polski w Warszawie.

\section{Program PRAC KONSERWATORSKICH I REKONSTRUKCJI}

1. Dokumentacja fotograficzna i opisowa zabytku.

2. Rozpulchnienie zanieczyszczeń powierzchniowych w kąpieli zimnej wody destylowanej.

3. Oczyszczenie mechaniczne powierzchni zabytku. 
4. Neutralizacja związków taninowych i żelazistych.

5. Neutralizacja odczynu kwasowego, wielokrotne płukanie pod bieżącą wodą.

6. Impregnacja struktury zabytku.

7. Zamrażanie zaimpregnowanego przedmiotu $\mathrm{w}$ temperaturze bliskiej $-20^{\circ} \mathrm{C}$.

8. Stabilizacja procesów impregnacji metodą freeze-drying.

9. Dokumentacja fotograficzna zabytku.

10. Wykonanie częściowego dublażu rękawicy.

11. Wykonanie rekonstrukcji wykroju kciuka.

12. Wykonanie szwów łączących krawędzie zabytku.

13. Dokumentacja fotograficzna zabytku.

\section{DOBÓR SUROWCów}

Do rekonstrukcji wykorzystano szereg współczesnych surowców, które wytypowano spośród dostępnych obecnie na rynku.

Do uzupełnienia brakujących elementów rękawicy zastosowano dwoinę skóry bydlęcej, roślinnie garbowanej. Głównymi argumentami za jej wykorzystaniem były relatywnie wysoka odporność mechaniczna przy zadowalającej elastyczności skóry. Wykonanie wykroju kciuka, a następnie połączenie krawędzi szwem dwuigłowym na tzw. wywrotkę wymagało surowca pozwalającego na łatwe wywrócenie na stronę zewnętrzną. Również krawędzie styku substancji zabytkowej ze skórą współczesną uzyskały dzięki temu naturalne, wyprofilowane kształty. Dwoina posiada ponadto fakturę pozwalającą, nawet w przypadku zafarbowania jej na kolor zbliżony do barwy zabytku, na łatwe odróżnienie uzupełnień będących interpretacją konserwatora, od oryginalnej części rękawicy (ryc. 3, 4). W końcu wykorzystanie naturalnie garbowanej skóry nie stoi w opozycji do zastosowanych pierwotnie materiałów.

Częściowy dublaż zabytku wykonano klejem kontaktowym Globus produkcji Inter Globus sp. z o.o. Klej wytypowano w ramach testu przeprowadzonego na próbie czterech spoin. Kleje Globus (Inter Globus sp. z o.o.), Feniks (Inter Globus sp. z o.o.), Super Cement (Inter Globus sp. z o.o) oraz Butapren (Dragon sp. z o.o.) nałożono na zbliżonej wielkości fragmenty dwoiny skórzanej, roślinnie garbowanej, a po odczekaniu wskazanego przez producenta czasu nakryto podobnymi fragmentami dwoiny. Test powtórzono w kombinacjach dwoina czysta - dwoina czysta, dwoina czysta - dwoina impregnowana, dwoina impregnowana - dwoina impregnowana. Próbki pozostawiono na 24 godziny w celu utrwalenia spoin, a następnie poddano testom wytrzymałości, elastyczności oraz ocenie przezroczystości spoiny. Testy przeprowadzono organoleptycznie, w identycznych warunkach termicznych, przy takiej samej wilgotności próbek. 
Zdecydowano się na zastosowanie $\mathrm{w}$ teście dwoiny skórzanej z powodu wyboru tego surowca do wykonania częściowego dublażu zabytku, a także przez wzgląd na sposób łączenia fragmentów skóry. Dublaż zakładał nałożenie spoin na mizdrę dwoiny oraz mizdrę skóry zabytkowej, nie zakładano konieczności nakładania spoiny na lico skóry. Próba wykazała, że najbardziej elastyczną, a przy tym wytrzymałą spoinę, uzyskano w przypadku kleju kontaktowego Globus. Substancja po związaniu staje się również przezroczysta lub bliska przezroczystej. Ponadto ulega szybkiej degradacji w kąpieli w toluenie, co umożliwia łatwe wyprowadzenie jej z substancji zabytkowej.

Do wykonania szwów wybrano nić lnianą, barwioną na ciemnobrązowy kolor. Przy niewielkiej średnicy, wynoszącej $0,35 \mathrm{~mm}$, nić zachowuje dostatecznie wysoką odporność mechaniczną, by umożliwić bezpieczne wywrócenie zabytku ze strony wewnętrznej, na zewnętrzną, po wykonaniu szwów metodą na tzw. wywrotkę. Ponadto, zbliżony kolor do barwy zabytku sprawia, że nawet w przypadku powstania niewielkich szczelin po wykonaniu szwów, nić nie będzie natarczywie widoczna $\mathrm{w}$ trakcie ekspozycji zabytku. Wykorzystano również wosk pszczeli naturalny, którym nacierano nić bezpośrednio przed szyciem, co zmniejszyło jej tarcie o krawędzie otworów, a także zwiększyło odporność nici na ewentualne zawilgocenie.

\section{Przebieg PRAC}

Po wykonaniu dokumentacji fotograficznej (ryc. 1) i opisowej przystąpiono do oczyszczania powierzchni zabytku. Rękawicę umieszczono w pojemniku, a następnie zanurzono w kąpieli wody destylowanej w temperaturze pokojowej. Płyn przyczynił się do częściowego rozpulchnienia zanieczyszczeń pokrywających lico i mizdrę skóry. Proces wspomagano mechanicznym oczyszczaniem powierzchni zabytku szczotkami i pędzlami o miękkim włosiu naturalnym oraz syntetycznym. Po usunięciu widocznych zanieczyszczeń przystąpiono do neutralizacji kwasów humusowych oraz związków żelazistych i taninowych, jakie działały na zabytek w trakcie jego zalegania w wilgotnej glebie. Skórę zanurzono w roztworze kwasu cytrynowego w wodzie destylowanej o stężeniu 3-5\%. Odbarwienie roztworu na kolor silnie żółty potwierdziło obecność związków żelazistych i taninowych w strukturze skóry. Kąpiel w roztworze kontynuowano przez około 24 godziny, a następnie rozpoczęto neutralizację odczynu kwasowego roztworu. Skórę umieszczono w 3\% roztworze amoniaku, a w dalszej kolejności w wodzie destylowanej, wielokrotnie zmienianej. Płukanie kontynuowano przez kolejne 72 godziny.

Oczyszczony, a następnie zneutralizowany zabytek umieszczono w impregnacie składającym się z kompozycji 12,5\% poliglikolu etylenowego - PEG 300 oraz $12,5 \%$ gliceryny roślinnej, rozcieńczonych wodą destylowaną. Do konser- 


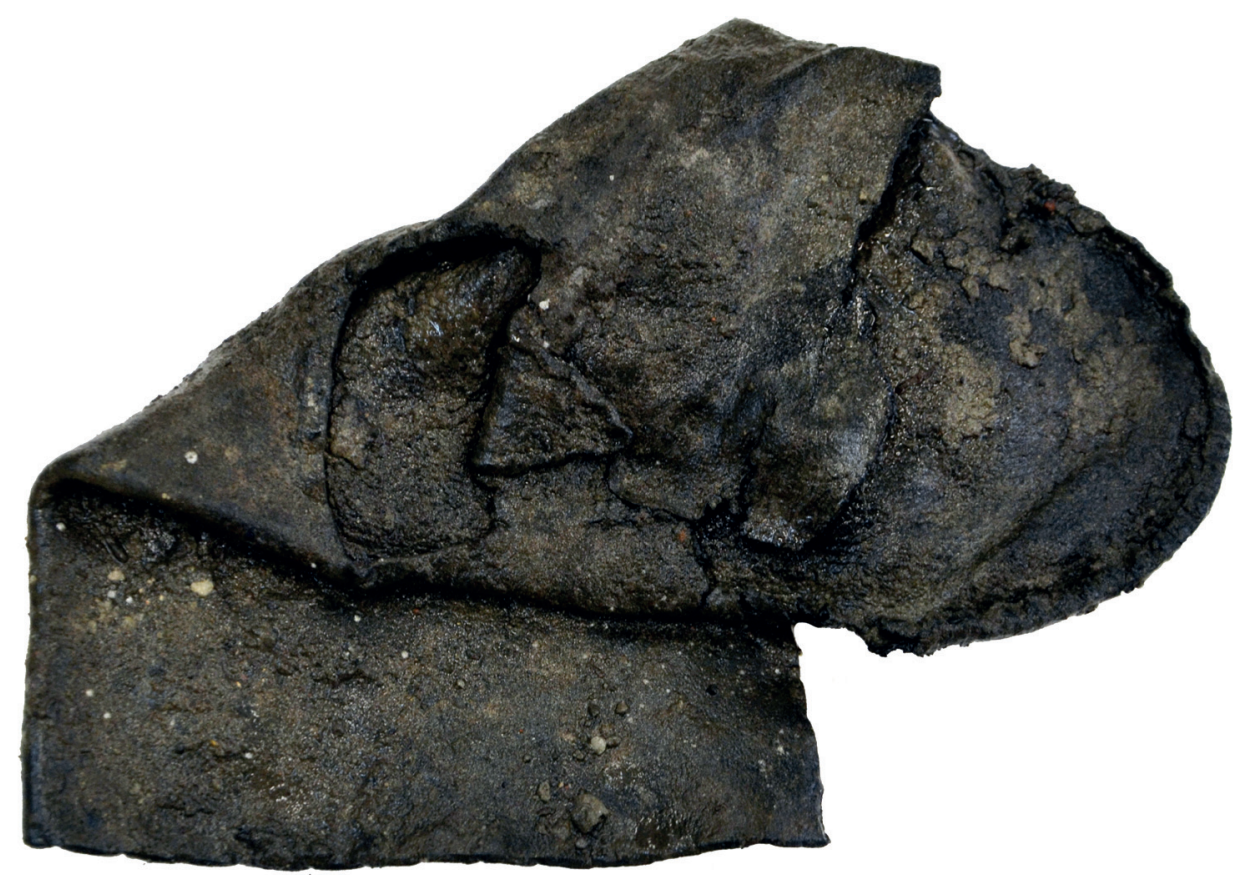

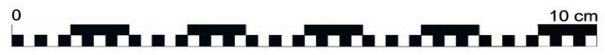

Ryc. 1. Rękawica skórzana nr inw. 789/2016, stan przed konserwacją (fot. S. Nowak).

wacji rękawicy wybrano PEG 300 przez wzgląd na niską wagę cząsteczkową, która ułatwia wnikanie środka w strukturę obiektów. Obecność PEG-u w impregnacie zapobiega powstawaniu zbyt dużych kryształów lodu, a także pełni funkcję środka nawilżającego, przeciwdziałającego nadmiernemu skurczowi zabytków w trakcie stabilizacji procesów z wykorzystaniem liofilizatora i sublimacji w warunkach ujemnych temperatur. Impregnację zabytku prowadzono przez kolejnych $7 \mathrm{dni}$, a następnie poddano go powolnemu procesowi zamrażania, stopniowo obniżając temperaturę od $-2^{\circ} \mathrm{C}$ do $-20^{\circ} \mathrm{C}$. Powolne, wielofazowe zamrażanie wspomaga rozdzielanie roztworu wodnego będącego składnikiem impregnatu, a także reguluje wielkość kryształów lodu, które powyżej pewnej wartości mogą przyczyniać się do deformacji struktury skóry archeologicznej (Drążkowska i in. 2011: 384; Grupa 2011: 32; 2014a: 303).

Stabilizację procesów impregnacji przeprowadzono w liofilizatorze metodą freeze-drying (Ślesiński 1995: 40-42; Starling 2001: 138-139; Drążkowska i in. 2011: 381-382; Grupa 2011: 32-33). Podczas stabilizacji wywołano efekt sublimacji roztworu wodnego oddzielonego od mieszaniny impregnatów w trakcie 
mrożenia. Poddawanie zabytku warunkom ujemnych temperatur, a następnie próżni, służy także zabezpieczeniu przed działaniem mikroorganizmów (Grupa 2011: 32; 2014a: 303).

Rękawicę po wyjęciu z komory liofilizatora poddano ponownie dokumentacji fotograficznej (ryc. 2), a następnie analizie mającej na celu odtworzenie pierwotnego jej kształtu. Wykonano częściowy dublaż przedmiotu w partii palców przy wykorzystaniu dwoiny skóry juchtowej, bydlęcej, roślinnie garbowanej. Grubość dwoiny dobrano tak, by po wykonaniu wszystkich szwów konstrukcyjnych, rekonstruowany przedmiot pozbawiony był toporności i sztucznie

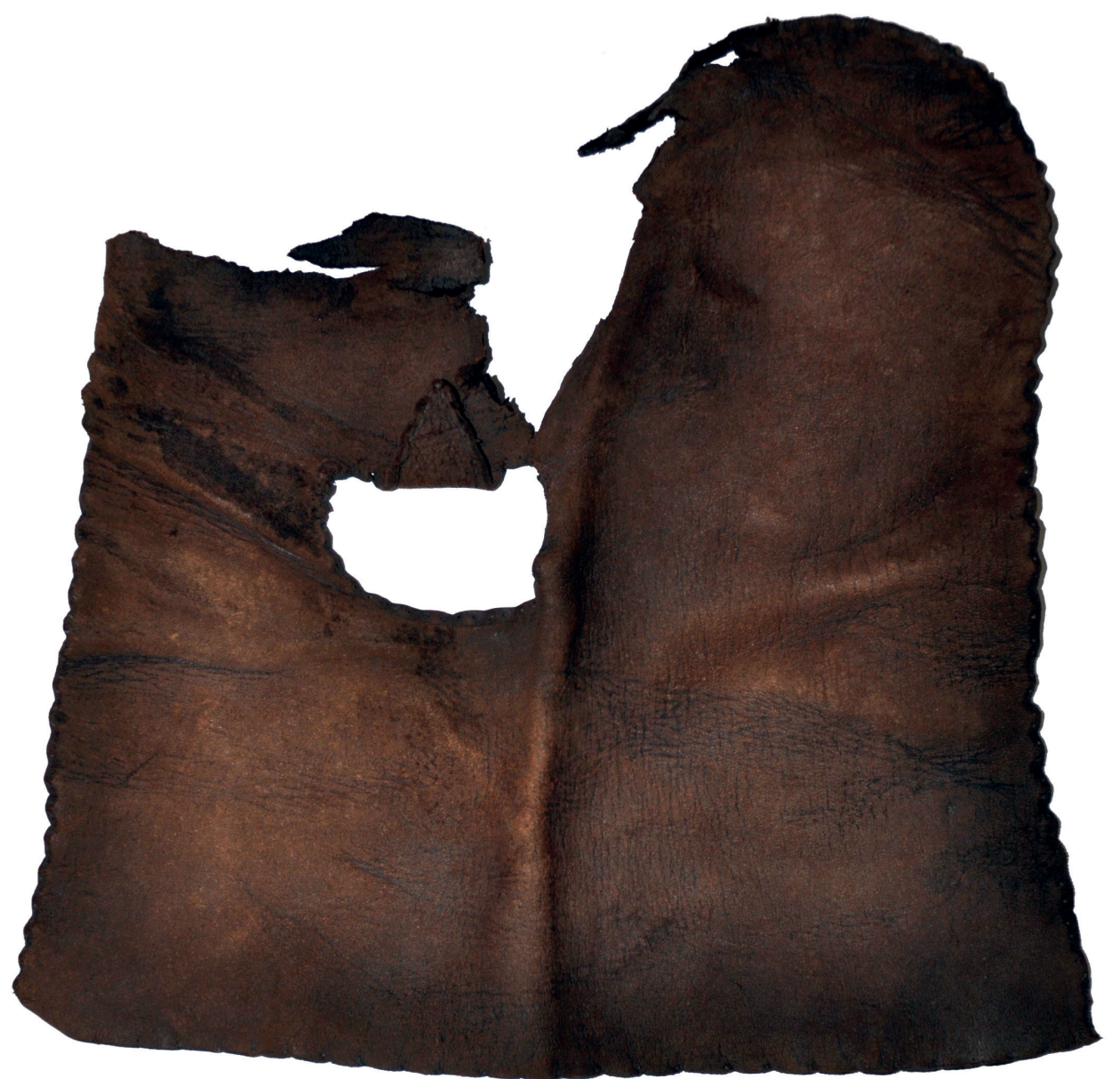

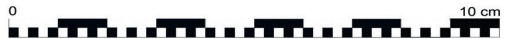

Ryc. 2. Rękawica skórzana nr inw. 789/2016, strona wierzchnia, stan po konserwacji

(fot. S. Nowak). 
wywołanej, przez źle układające się szwy, objętości. Wykonano niewielką zakładkę, a następnie dwoinę oraz mizdrę skóry zabytkowej połączono w sposób trwały klejem kontaktowym Globus. Po odczekaniu zalecanego przez producenta czasu na wiązanie spoiny oceniono jej wygląd, grubość, przezroczystość, a także wytrzymałość. W międzyczasie przygotowano wykrój kciuka z dwoiny skórzanej (ryc. 3). Wykonano szew łączący krawędzie substancji zabytkowej oraz przygotowanego kciuka, stosując technikę szwu dwuigłowego. Wykorzystano istniejące otwory po nici, w które wprowadzono nić lnianą, pokrytą cienką warstwą wosku pszczelego, naniesioną przez pocieranie nici bryłką wosku. Następnie wykonano pozostałe szwy konstrukcyjne rękawicy, a po zakończeniu szycia, zabytek wywrócono na stronę zewnętrzną. Fragment szwu na odcinku śródręcza i mankietu wykonano inną techniką, złożonej fastrygi, słabiej zaciągając nić w obawie przed przetarciem oryginalnych otworów w skórze zabytkowej. Krawędź mankietu wykończono dodatkowo rzadkim ściegiem na tzw. okrętkę, wykorzystując oryginalne otwory po wcześniejszym szwie (ryc. 4). Po zakończeniu prac wykonano dokumentację fotograficzną zabytku. Wnętrze rękawicy wypełniono sztywną gąbką syntetyczną, co pomogło uzyskać pożądany, naturalny kształt rękawicy.

\section{ZNACZENIE REKONSTRUKCJI ZABYTKÓW ARCHEOLOGICZNYCH}

Obecnie zagadnienie wykonywania rekonstrukcji zabytków archeologicznych staje się coraz częściej dyskutowanym tematem. Część środowiska skłania się ku zaprzestaniu wykorzystywania artefaktów jako materii powstających rekonstrukcji, proponując wykonywanie kopii zabytków w oparciu o informacje uzyskane $\mathrm{w}$ ramach ich opracowywania. W takim przypadku konieczne jest wierne odwzorowanie wszystkich technik użytych podczas produkcji danego przedmiotu z uwzględnieniem doboru surowców, z jakich wykonano zabytek. Metoda wydaje się zdecydowanie bardziej kosztowna niż rekonstrukcja przedmiotu z częściowym ubytkiem powierzchni, wymaga też większego nakładu czasu i pracy. W trakcie rekonstrukcji konserwator rozpoczyna rywalizację z rzemieślnikiem historycznym, który wykonał dany przedmiot, stara się dorównać mu kunsztem i doświadczeniem, by wytworzona kopia bez wstydu mogła być eksponowana obok destruktów przedmiotu zabytkowego. Inna propozycja zakłada pozostawienie przedmiotu po konserwacji w stanie bez rekonstrukcji, a w efekcie ekspozycję i upublicznianie zabytków z obrazem częściowej destrukcji (ryc. 2). Wydaje się jednak, że przynajmniej dla części turystów, a czasem i naukowców niezaznajomionych w sposób wystarczający z tematem dawnego rzemiosła, odbiór zabytku może okazać się utrudniony, momentami nawet niemożliwy lub przekłamany. Zrozumienie niektórych technologii wytwórczych czy zagadnień takich jak przeznaczenie poszczególnych przedmio- 
tów, ich funkcja i sposób użytkowania, wymagają umiejętnej ekspozycji, zawierającej odpowiednią narrację i przekaz pozwalający odbiorcy na samodzielne wnioskowanie, ocenę całości, stymulujący wyobraźnię, a niekiedy i zmysły. $\mathrm{Z}$ tego też powodu rekonstrukcja opracowanego artefaktu pozwalająca na przestrzenną prezentację (ryc. 3,4), najlepiej uzupełnioną tematycznie zgodnym tłem, wydaje się jedną z dogodniejszych form przedstawiania historii.

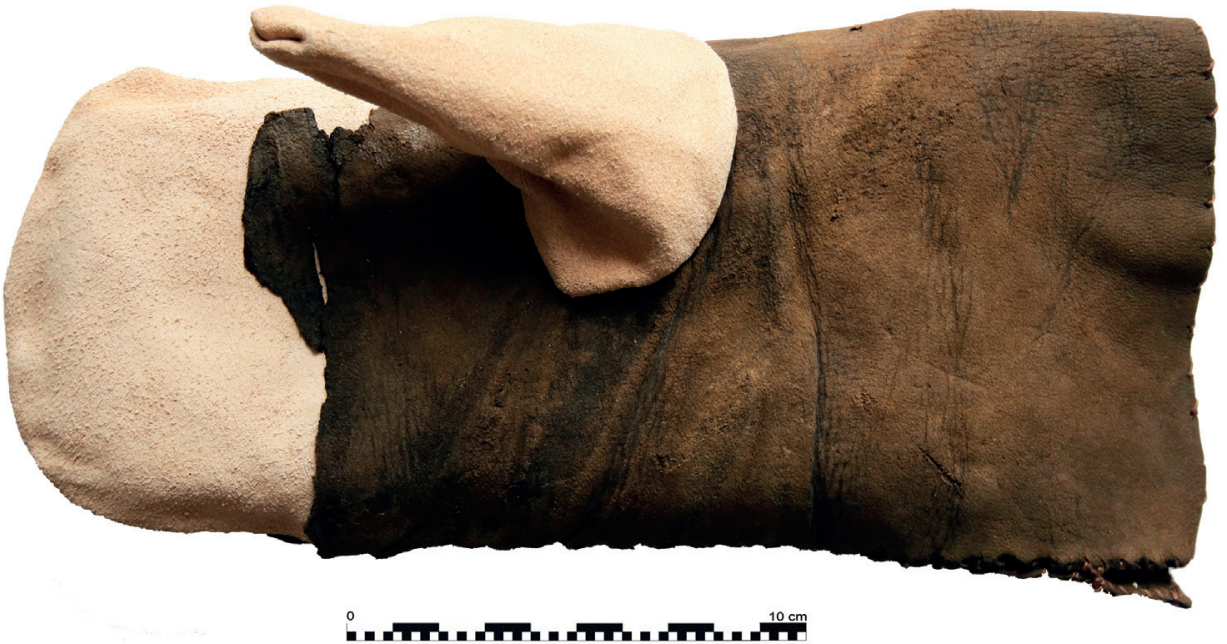

Ryc. 3. Rękawica skórzana nr inw. 789/2016, widok od strony chwytnej, stan po rekonstrukcji (fot. S. Nowak).

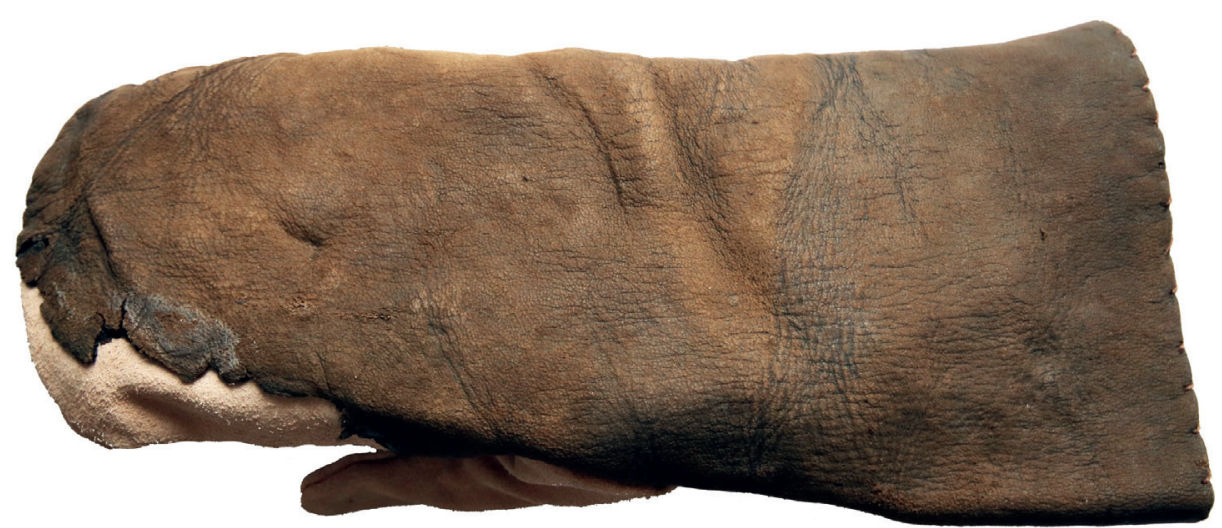

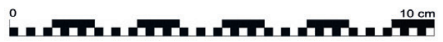

Ryc. 4. Rękawica skórzana nr inw. 789/2016, widok od strony zewnętrznej, stan po rekonstrukcji (fot. S. Nowak). 
Sebastian Nowak

Pracownia Dokumentacji i Konserwacji

Instytut Archeologii

Uniwersytet Mikołaja Kopernika w Toruniu

ul. Szosa Bydgoska 44/48

87-100 Toruń

e-mail: snowak@doktorant.umk.pl

\section{BibLIOGRAFIA}

Ceynowa B. (2009), Rękawice skórzane z badań gdańskich w sezonach 2005-2007, [w:] A. Janowski, K. Kowalski, S. Słowiński (red.), Acta Archaeologica Pomoranica III, Stowarzyszenie Naukowe Archeologów Polskich Oddział w Szczecinie, Szczecin, s. 229-239.

Drążkowska A., Grupa M., Płóciennik P., Rybka K., Szatkowski J., Zawadzka A. (2011), Using vaccum drying in low temperatures technique for cultural heritage objects of leather conservation. Wykorzystanie techniki suszenia próżniowego w niskich temperaturach do konserwacji zabytkowych skór, „Sprawozdania Archeologiczne" t. 63, s. 353-381.

Eberle L. (1970), Rękawica średniowieczna, „Z otchłani wieków”, r. 36, s. 260-264.

Grupa M. (2011), Konserwacja organicznych zabytków archeologicznych z Chojnic, „Baszta”, nr 11, s. 31-36.

Grupa M. (2014a), Problematyka konserwatorska zabytków wydobytych z nawarstwień podwodnych mostu zachodniego, [w:] A. Kola, G. Wilke (red.), Wczesnośredniowieczne mosty przy Ostrowie Lednickim, t. 2, Mosty traktu poznańskiego, Universitas, Kraków, s. 299-308.

Grupa M. (2014b), Suche czy mokre, problematyka konserwatorska na stanowiskach archeologicznych w kontekście badań na Reducie Ordona, [w:] W. Borkowski, N. Kasparek (red.), Badania archeologiczne na Reducie Ordona, t. 1 (= Warszawskie Materiaty Archeologiczne 11), Państwowe Muzeum Archeologiczne w Warszawie, Warszawa, s. 125-136.

Nowak S. (2017), Konserwacja i rekonstrukcja skórzanej rękawicy z Wyspy Spichrzów w Gdańsku, Dokumentacja konserwatorska, Toruń, maszynopis dostępny w archiwum PDiKZ Instytutu Archeologii Uniwersytetu Mikołaja Kopernika w Toruniu.

Rębkowski M., Polak Z., Wywrot B. (1998), Źródła archeologiczne, [w:] M. Rębkowski (red.), Archeologia średniowiecznego Kołobrzegu, t. 3, Instytut Archeologii i Etnologii Polskiej Akademii Nauk, Kołobrzeg, s. 13-168.

Rosa H., Gussmann-Bannach L., Michaś A. (1995), Konserwacja zabytkowych skór archeologicznych, „Ochrona zabytków”, r. 48, nr 2, s. 206-214.

Samsonowicz A. (1982), Wytwórczość skórzana w Polsce wczesnofeudalnej, Zakład Narodowy im. Ossolińskich, Wydawnictwo Polskiej Akademii Nauk, WrocławWarszawa-Kraków-Gdańsk-Łódź.

Starling K. (2001), Conservation, [w:] F. Grew, M. de Neergaard (red.), Shoes and Pattens, Medieval Finds from Excavations in London, vol. 2, Museum of London, London, s. 137-139. 
Ślesiński W. (1995), Konserwacja zabytków sztuki, t. 3, Rzemiosto artystyczne, Arkady, Warszawa.

Turnau I. (1975a), Skórnictwo odzieżowe w Polsce XVI-XVIII wieku, Zakład Narodowy im. Ossolińskich, Wydawnictwo Polskiej Akademii Nauk, Wrocław-WarszawaKraków-Gdańsk.

Turnau I. (1975b), Garbarstwo na ziemiach polskich w XVI-XVIII wieku, Zakład Narodowy im. Ossolińskich, Wydawnictwo Polskiej Akademii Nauk, Wrocław-Warszawa-Kraków-Gdańsk.

Turnau I. (1983), Polskie skórnictwo, Zakład Narodowy im. Ossolińskich, Wydawnictwo Polskiej Akademii Nauk, Wrocław-Warszawa-Kraków-Gdańsk-Łódź.

Wywrot B. (1996), Wyroby skórzane, [w:] M. Rębkowski (red.), Archeologia średniowiecznego Kołobrzegu, t. 1, Instytut Archeologii i Etnologii Polskiej Akademii Nauk, Kołobrzeg, s. 243-284.

Wywrot-Wyszkowska B. (1998), Znaleziska skórzane, [w:] M. Rębkowski (red.), Archeologia średniowiecznego Kołobrzegu, t. 3, Instytut Archeologii i Etnologii Polskiej Akademii Nauk, Kołobrzeg, s. 229-251.

Wywrot-Wyszkowska B. (2008), Skórnictwo w lokacyjnym Kołobrzegu. XIII-XV wiek, Instytut Archeologii i Etnologii Polskiej Akademii Nauk, Szczecin.

\section{SUMmary}

\section{CONSERVATION AND RE CONSTRUCTION OF A LEATHER GLOVE FROM WYSPA SPICHRZÓW IN GDAŃSK}

The article presents brief characteristics of protective gloves, based on an example of an artifact excavated during archaeological exploration of a "Babel" granary at Żytnia street in Gdańsk. The object was treated and reconstructed in The Documentation and Conservation Laboratory of The Institute of Archaeology, NCU in Torun. The article includes conservation issues, the program and description of treatments implemented working on the object, as well as the problem of importance of archaeological objects' reconstruction to demonstrate technological processes and crafts of creating the items, especially to the public not being involved in scientific problems and having difficulties in perception of destroyed artifacts, deprived of their cultural contexts. 